\title{
KARYA KREATIF YANG MEMPUNYA NILAI EKONOMIS DENGAN PEMANFAATAN SAMPAH RUMAH TANGGA DI KELURAHAN SUNGAI PELUNGGUT, KECAMATAN SAGULUNG BATAM PROVINSI KEPULAUAN RIAU
}

\author{
ECONOMIC VALUE CREATIVE WORKS BY UTILIZING HOUSE WASTE AT \\ SUNGAI PELUNGGUT, SAGULUNG BATAM, KEPULAUAN RIAU PROVINCE
}

\author{
Mira Yona \\ Program Studi manajemen, Fakultas Ekonomi, \\ Universitas Riau Kepulauan, Indonesia, \\ mira@unrika.ac.id
}

\begin{abstract}
Abstrak
Kelurahan Sungai Pelunggut adalah salah satu kelurahan yang berada di kecamatan Sagulung Kota Batam, Kelurahan ini memiliki luas wilayah 5,2 Km² dengan jumlah penduduk 19.292 Jiwa. Berdasarkan penelitian yang di lakukan Kelurahan Sungai Pelunggut ini menghasilkan sampah terbanyak nomor tiga setelah Tiban Kampung, untuk mengurangi kuantitas sampah di Sungai Pelunggut ini, maka diadakanlah gerakan pemanfaatan sampah oleh ibu- ibu rumah tangga, dengan cara mengolah sampah menjadi produk yang bernilai ekonomis, yang tujuannya adalah menimbulkan kesadaran akan bahayanya sampah, mengurangi pencemaran lingkungan, menambah pendapatan keluarga, dan menjadikan hidup sehat. Metode yang dilakukan dalam penelitian ini adalah analisa permasalahan, pemanfaatan limbah sampah dengan melibatkan Dinas Terkait,dengan cara memberikan berbagai macam pelatihan pembuatan produk dari sampah rumah tangga yang mempunyai nilai ekonomis, memonitor dan mendampingi proses selama kegiatan berlangsung dan membantu kegiatan pemasaran produk yang di hasilkan oleh ibu- ibu rumah tangga dengan cara melakukan kerjasama dengan dinas pasar, industry, swasta, dan dinas terkait lainnya, dengan adanya kegiatan ini manfaat yang dirasakan oleh masyarakat adalah , kurangnya sampah yang berserakan karna masyarakat sudah sadar akan bahayanya sampah dan pentingnya sampah dengan cara memanfaatkan sampah untuk menambah pendapatan keluarga, serta berkurangnya pencemaran lingkungan yang disebabkan oleh sampah dan berkurangnya penyebaran penyakit. Hidup lebih sehat.
\end{abstract}

Kata Kunci :Bahaya Sampah,Produk Kreatif, Penambahan Income Keluarga

\begin{abstract}
Sungai Pelenggut area is one of sub-districts which located at Sagulung district, Batam City. This area is 5.2 $\mathrm{km}^{2}$ with population, 19,292. Based on the research was conducted at Sungai Pelinggut area, it was it produced the third largest waste after Tiban Kampung. To minimize the quantity of Sungai Pelenggut waste, waste utilization program was done by housewives, making a valueable goods, with goals were to generate societies' awareness of the dangersous of waste, to minimize environmental pollution, to increase income, and to make a healthier life. The method used in this research was problem analysis, waste utilization program with Related Office supports by providing various training of product manufacture using home waste which had economic value, monitoring and mentoring process during the activity and assisting product marketing strategy by holding a cooperation with the market agency, industry, private, and other related agencies. Through this activity, the benefits were scattered waste problem could be minimized due to increasing awareness of society about dangersous of waste and the benafit of waste utilizing to support income, and reduced environmental pollution caused by waste and reduced disease spread as well. Life is healthier.
\end{abstract}


Keywords: Dangerous Of Waste, Creative Product, Addition Income

\section{PENDAHULUAN}

Menurut definisi World Health Organization (WHO) sampah adalah sesuatu yang tidak digunakan, tidak dipakai, tidak disenangi atau sesuatu yang dibuang yang berasal dari kegiatan manusia dan tidak terjadi dengan sendirinya (Chandra, 2006). Undang-Undang Pengelolaan Sampah Nomor 18 tahun 2008 menyatakan sampah adalah sisa kegiatan seharihari manusia dan/atau dari proses alam yang berbentuk padat. Sampah dapat mengakibatkan berbagai permasalahan baik dari segi kesehatan maupun lingkungan.Apalagi peningkatan volume sampah terus terjadi setiap tahunnya, khususnya di Indonesia sendiri sebagai negara berkembang, permasalahan sampah menjadi masalah yang harus mendapat perhatian lebih seiring laju pertumbuhan penduduk yang terus meningkat setiap tahunnya.

Pada tahun 2008 KNLH (Kementrian Negara Lingkungan Hidup) mengatakan jika Indonesia setiap tahunnya menghasilkan sampah sebanyak 38,5 juta ton sedangkan pada tahun tahun 2011 jumlah tersebut terus meingkat menjadi 200 ribu ton/hari

Jenis-jenis sampah sendiri, menurut Alex (2012) terbagi menjadi dua, yaitu;

1. Sampah organik, sampah organik adalah barang buangan yang dihasilakan dari sisa makanan misalnya barang seperi ini ialah daging, sayuran, duan, kertas, dan sebagainya.

2. Sampah anorganik, sampah ini dihasilakan dari sisa material sintetis yang tidak mudah teruraikan seperti hanya plastik, baja, logam, kaca, keramik, seng, dan sebagainya.

Sungai Pelungut adalah salah satu Kelurahan yang berada di Kecamatan Sagulung, dengan Luas Wilayah $5,3 \mathrm{~km}^{2}$ yang berjumlahkan penduduk 23.000 jiwa atau $7.865 \mathrm{KK}$. Dengan padatnya penduduk Sungai Pelungut kesadaran masyarakat akan kesehatan sangat memprihatinkan, dimana sepanjang jalan terlihat sampah yang berserakan dan terganggunya saluran pembuangan air, sehingga menimbulkan bau yang busuk dan jentik- jentik nyamuk yang berada di genangan air.Menurut data Dinas Lingkungan Hidup Kelurahan Sungai Pelunggut termasuk penghasil sampah nomor 3 terbesar setelah tiban kampung.

\section{Dampak Sampah bagi Kesehatan}

Berdasarkan paparan diatas dan tinjauan lokasi, masyarakat banyak mengeluh karna banyaknya sampah yang berserakan di lingkungan mereka, dan bau busuk yang di bawa angin kepemungkinan penduduk setiap harinya.Lokasi dan pengelolaan sampah yang kurang baik 
(pembuangan sampah yang sembarangan) merupakan tempat yang cocok bagi beberapa organisme dan menarik bagi berbagai binatang seperti anjing, lalat, kecoa yang dapat menimbulkan penyakit.

Menurut Gelbert dkk (1996;46-48) Potensi bahaya kesehatan yang dapat ditimbulkan oleh sampah adalah sebagai berikut :

1. Penyakit Diare, kolera, tifus menyebar dengan cepat karena virus yang berasal dari sampah dengan pengelolaan yang tidak tepat dapat bercampur dengan air minum atau makanan. Penyakit demam berdarah dapat juga meningkat dengan cepat didaerah yang pengelolahan sampahnya tidak baik

2. Penyakit jamur yang sering menyerang kulit

3. Sampah beracun, telah dilaporkan bahwa dijepang kira- kira 40.000 orang meninggal akibat mengkonsumsi ikan yang telah terkontaminansi oleh raksa (Hg). Raksa ini berasal dari sampah yang dibuang ke laut oleh pabrik yang memproduksi baterai dan akumulator.

\section{Dampak sampah bagi lingkungan}

a. Pencemaran udara

Sampah yang menumpuk dantidak segera diangkut merupakan sumber bau tidak sedap yang memberi efek buruk bagi lingkungan sekitarnya.Pembakaran sampah sering kita temui apabila pengangkutan sampah tidak ada.Asap yang timbul sangat potensi menimbulkan gangguan bagi lingkungan sekitarnya.Sampah yang berserakan di sepanjang jalan dan pemungkiman penduduk menimbulkan masalah bau di sepanjang jalur yang dilalui. Proses dekomposisi sampah di TPA secara kontinu akan berlangsung dan dalam hal ini akan dihasilkan berbagai gas seperti $\mathrm{CO}, \mathrm{CO} 2, \mathrm{CH} 4, \mathrm{H} 2 \mathrm{~S}$, dan lain- lain yang secara langsung akan mengganggu komposisi gas alamiah di udara, mendorong terjadinya pemanasan global, disamping efek yang merugikan terhadap kesehatan manusia di sekitarnya.

b. Pencemaran Tanah

Pembungan sampah sembarangan akan menyebabkan lahan setempat mengalami pencemaran akibat tertumpuknya sampah organic dan mungkin juga mengandung Bahan Buangan Berbahaya (B3). Bila hal ini terjadi maka akan diperlukan waktu yang sangat lama sampai sampah terdegradasi atau larut dari lokasi tersebut. Selama waktu itu lahan setempat berpotensi menimbulkan pengaruh buruk terhadap manusia dan lingkuan sekitarnya.

c. Pencemaran Air 
Prasarana dan sarana pengumpulan yang terbuka sangat potensial menghasilkan lindi terutama pada saat turun hujan. Aliran lindi ke saluran atau tanah sekitarnya akan menyebabkan terjadinya pencemaran. Instalasi pengolahan berskala besar menampung sampah dalam jumlah yang cukup besar pula sehingga potensi lindi yang dihasilkan di instalasi juga cukup potensial untuk menimbulkan pencemaran air dan tanah di sekitarnya.Lindi yang timbul di TPA sangat mungkin mencemari lingkungan sekitarnya baik berupa rembesan dari dasar TPA yang mencemari air, tanah di bawahnya. Pada lahan yang terletak di kemiringan, kecepatan aliran air tanah akan cukup tinggi sehingga dimungkinkan terjadi cemaran terhadap sumur penduduk yang terletak pada elevasi yang lebih rendah. Banyak jenis pencemaran yang akan terjadi jika kurangnya kesadaran masyarakat untuk hidup bersih dan sehat, selalu membuang sampah tidak pada tempatnya.

Berdasarkan landasan dan latar belakang tersebut peneliti tertarik untuk menyusun sebuah Strategi Pengolahan Sampah Anorganik di Kelurahan Sungai Pelunggut yang dapat mengurangi sampah dan pencemaran .Diharapkan dengan Pemanfaatan Sampah Anorganik ini dapat meningkatkan derajat kesehatan masyarakat dengan cara menurunkan jumlah kasus penyakit oleh pencemaran lingkungan dan dapat membantu menambahan ekonomi keluarga dengan hasil karya kreatif berbahankan sampah masyarakat yang di olah oleh ibuibu kreatif, . Selain daripada itu juga merekomendasikan kepada Dinas Lingkungan Hidup untuk dapat memperhatikan dan membantu ibu- ibu rumah tangga dalam hal pelatihan pembuatan produk kreatif, dan pendistribusian produk.

\section{METODOLOGI}

Metodologi penelitian ini adalah metode deskriptif yang dilakukan untuk mengetahui gambaran atau deskripsi tentang suatu keadaan secara objektif.Metode penelitian ini digunakan untuk memecahkan atau menjawab permasalahan yang dihadapi sekarang. Prosedur yang digunakan adalah metode purposive yaitu cara pemilihan subjek penelitian yang di dasarkan atas adanya tujuan tertentu dan pertimbangan. Dimana pertimbangan pertimbangan tersebut berdasarkan populasi masyarakat setempat. Adapun langkah- langkah analisa data yang dilakukan adalah sebagai berikut : tahap 1 persiapan dengan melakukan survey lapangan, tahap ke 2 identifikasi masalah, tahap ke 3 strategi pengurangan sampah dengan melibatkan dinas terkait yaitu dinas lingkungan hidup sebagai nara sumber. 
Figure 1. Sketma Metodologi Penelitian;

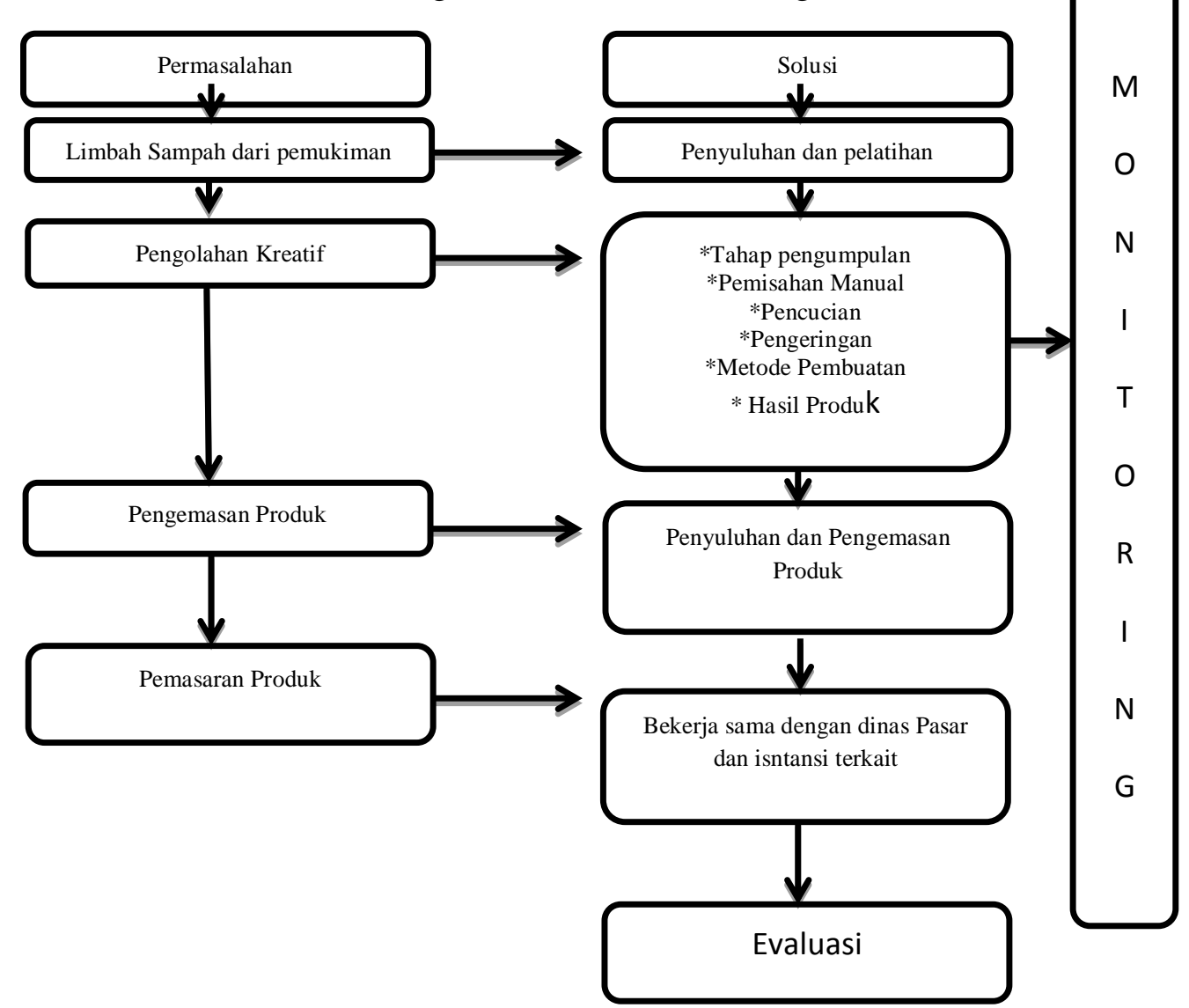

\section{PEMBAHASAN}

\section{Kondisi Lingkungan di Kelurahan Sungai Pelungut}

Sungai Pelunggut dengan luas wilayah adalah : 5,2 $\mathrm{Km}^{2}$, dengan jumlah RT sebanyak 70 dan RW 18. Wilayah Kelurahan Sungai Pelunggut terdiri dari KSB dan Daerah Pinggiran/ pemungkinan Lama.Potensi daerah adalah pertanian, perikanan dan Industri.

Tabel. 1 Jumlah Penduduk Sungai Pelunggut

\begin{tabular}{lll}
\hline Jenis Kelamin & Jumlah & Persentase \\
\hline Laki- laki & 10.186 Jiwa & 50,27 \\
Perempuan & 9.106 Jiwa & 40,72 \\
\hline Total & $\mathbf{1 9 . 2 9 2 ~ J i w a ~}$ & $\mathbf{1 0 0 \%}$ \\
\hline
\end{tabular}




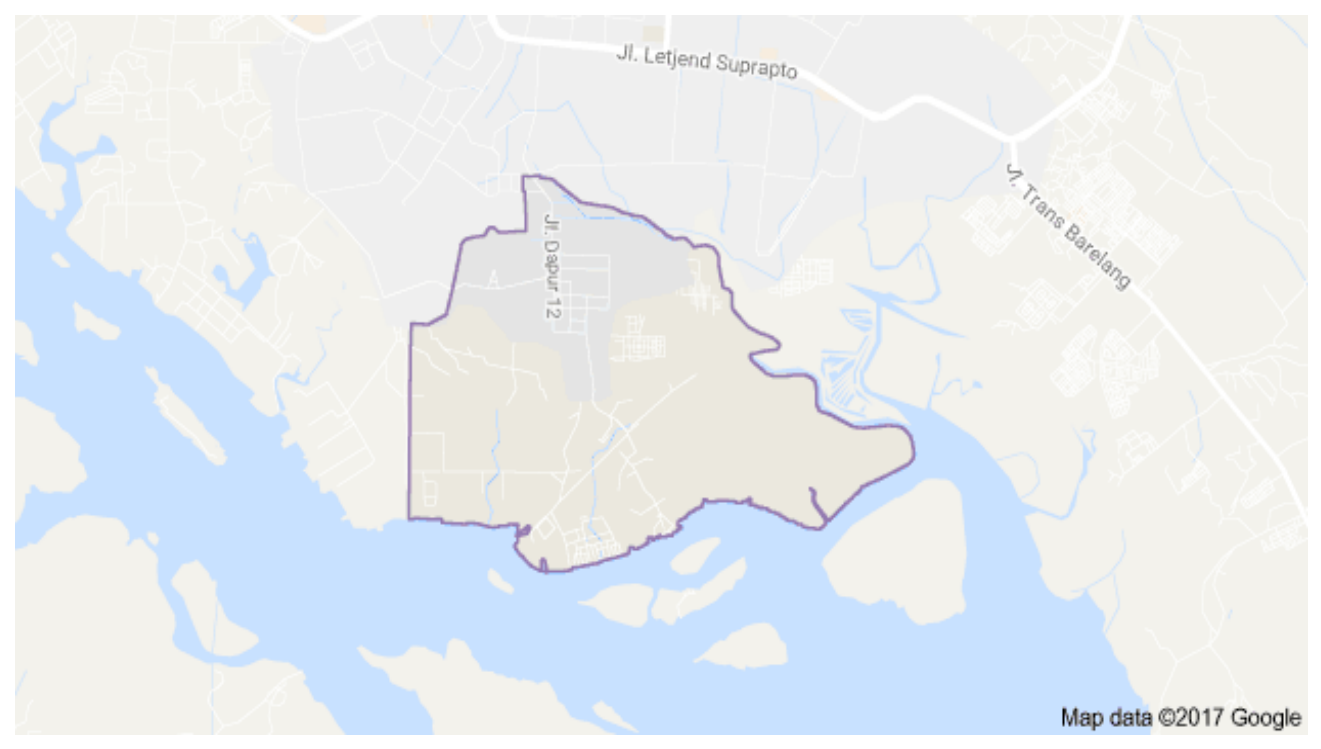

Gambar 1.Denah Lokasi Sungai Pelunggut

\section{A. Lokasi Pencemaran lingkungan}

Dari survey lapangan yang di lakukan ada 3 (tiga) lokasi terbesar pembuangan sampah masyarakat yang cukup banyak yaitu sebagai berikut :

1. Didepan jalan umum pasar kaget ruko Mandalay

2. Di aliran hutan bakau tepatnya di belakang perumahan Kamboja RT 05 RW 15

3. Dibawah Jembatan Nato Simpang lampu merah dapir 12

Kebiasaan masyarakat membuang sampah mulai pukul 5 pagi sampai pukul 8 pagi dengan cara melemparkan sampah langsung dari kendaraan motor maupun kendaraan mobil, hal ini lah yang mengakibatkan sampah menumpuk dan terjadinya berbagaimacam pencemaran.

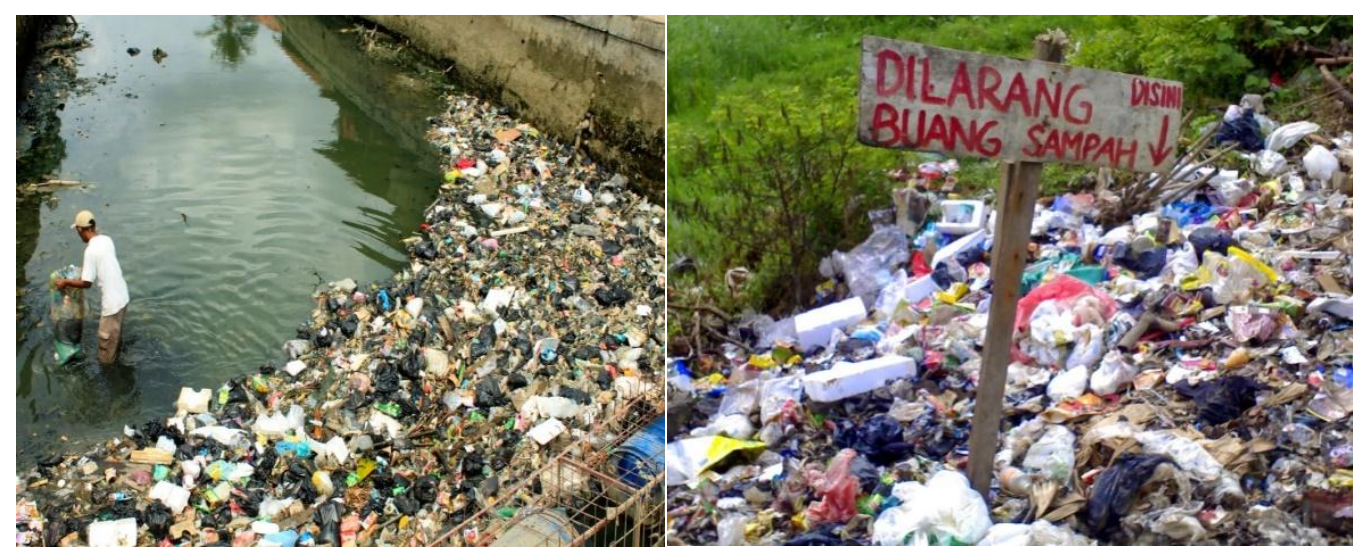




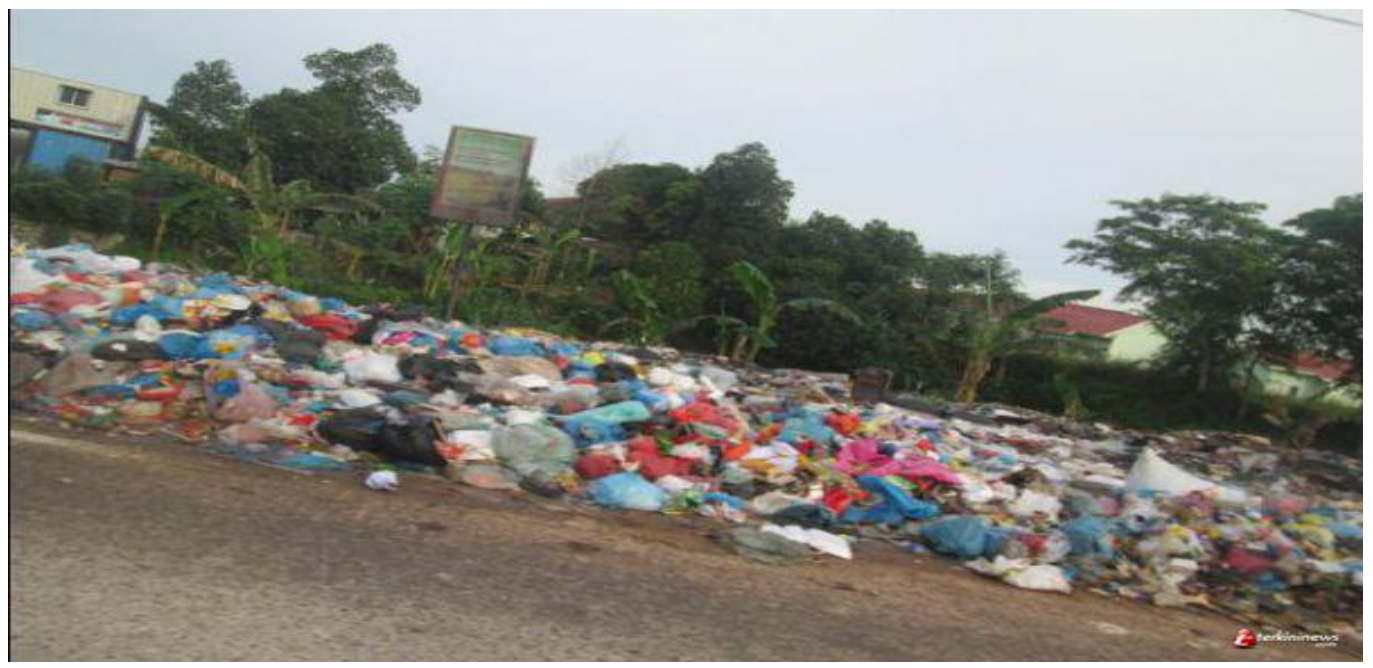

Gambar.2 Lokasi Pembuangan Sampah

B. Strategi pengurangan sampah

1. Sejarah

Pengelolaan Kebersihan Kota Batam pada awalnya dilakukan oleh Badan Pengelola (BP) Kebersihan yang dibentuk melalui SK Bersama antara Walikota Madya Batam dengan Kepala Satuan Pelaksana Otorita Batam No.KPTS : 20/XI/1994 dan No : 06/SKEP/ KASATLAK/ OB/XI/1994 tanggal 12 November 1994. Sejalan dengan pelaksanaan Undang-undang No. 22 Tahun 1999 tentang Pemerintah Daerah yang diganti dengan Undang-Undang No. 32 Tahun 2004 dan Undang-undang No. 53 tahun 1999 tentang tentang Pembentukan Kabupaten Pelalawan, Kabupaten Rokan Hulu, Kabupaten Rokan Hilir, Kabupaten Siak, Kabupaten Karimun, Kabupaten Natuna, Kabupaten Kuantan Singingi, dan Kota Batam, maka kewenangan tersebut diserahkan kepada Dinas Kebersihan dan Pertamanan Kota Batam.

Penyerahan pengelolaan kebersihan dari BP Kebersihan kepada Dinas Kebersihan dan Pertamanan dilakukan berdasarkan Berita Acara No. 05/KA/KB/II/2001, tanggal 16 Februari 2001 tentang penyerahan pengelolaan kebersihan dari Badan Pengelola Kebersihan kepada Dinas Kebersihan dan Pertamanan Kota Batam .Pada Tahun 2003, Dinas Kebersihan dan Pertamanan Kota Batam berubah menjadi Dinas Pasar dan Kebersihan Kota Batam berdasarkan Peraturan Daerah Kota Batam No. 6 Tahun 2003 Tentang Pembentukan Susunan Organisasi dan Tata Kerja Dinas Daerah Kota Batam. Saat ini Dinas Kebersihan dan Pertamanan Kota Batam berganti nama menjadi Dinas Lingkungan Hidup. 
Visi Dinas Lingkungan Hidup Kota Batam bermakna :

- Bersih menciptakan atau menjadikan lingkungan yang bersih

- Hijau pemanfaatan ruang terbuka hijau

- Asri menjadikan lingkungan yang indah dan sedap dipandang oleh setiap orang yang melihat dan tertata dengan baik

- Melalui Partisipasi Masyarakat pemberian usul, pertimbangan dan/atau saran kepada Pemerintah Daerah mengenai pengelolaan sampah di daerah; pemberian saran dan pendapat dalam perumusan kebijakan dan strategi pengelolaan sampah; pelaksanaan kegiatan penanganan sampah rumah tangga dan sampah sejenis sampah rumah tangga yang dilakukan secara mandiri dan/atau bermitra dengan Pemerintah Daerah; dan/atau pemberian pendidikan dan pelatihan, kampanye, dan pendampingan oleh kelompok masyarakat kepada anggota masyarakat dalam pengelolaan sampah untuk mengubah perilaku anggota masyarakat.

Misi Dinas Lingkungan Hidup Kota Batam Untuk mewujudkan visi tersebut akan ditempuh dengan misi Dinas Kebersihan dan Pertamanan Kota Batam, yaitu

1. Meningkatkan penataan, pelayanan dan pengelolaan sampah yang berwawasan lingkungan

2. Meningkatkan pembinaan dan peran serta masyarakat dalam pembudayaan hidup bersih

3. Mewujudkan penataan taman kota, ruang terbuka hijau yang bersih, hijau dan asri.

Dinas Lingkungan Hidup Kota Batam dibentuk berdasarkanPeraturan Daerah (Perda) Kota Batam No. 12 Tahun 2007 tentang PembentukanOrganisasi dan Kerja Dinas Daerah Kota Batam dengan struktur organisasi Dinas Lingkungan Hidup Kota Batam terdiri dari : 


\section{Figur 2. Struktur Organisasi}

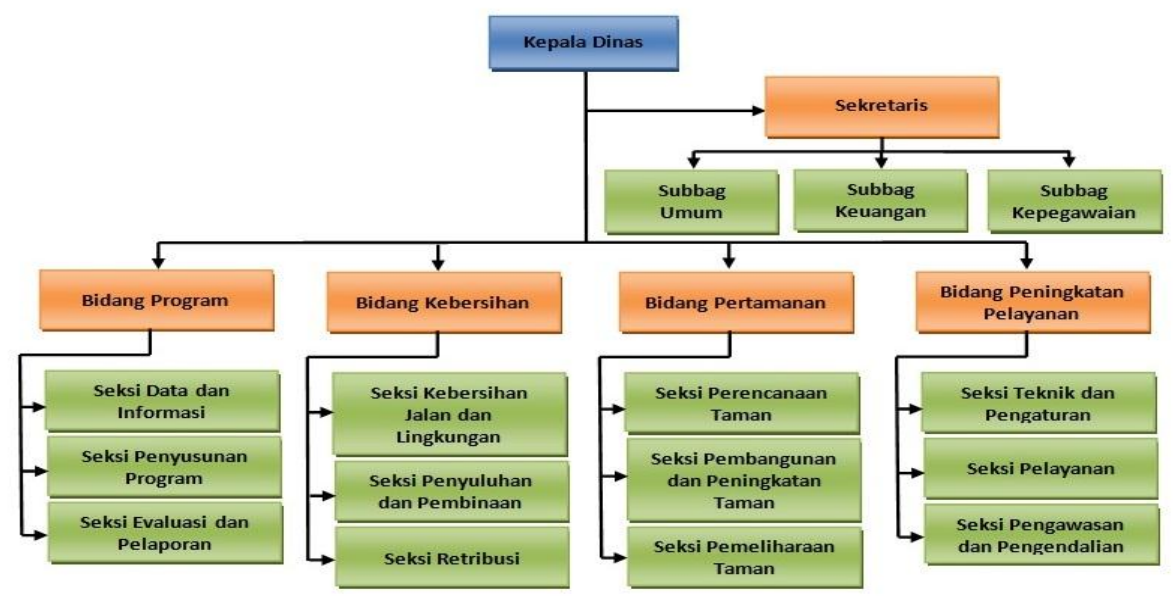

\section{Pelatihan Dari Dinas Terkait}

Untuk mengurangi sampah yang bertumpuk khususnya di Sungai Pelunggut, maka di undanglah Dinas Lingkungan Hidup sebagai nara sumber bekerjasama dengan penulis dalam rangka menciptakan lingkungan bersih.

Tujuan

1. Mengurangi sampah/Limbah plastic yang berasal dari sampah rumah tangga

2. Mengubah pola pikir masyarakat terhadap limbah sampah yang dapat dimanfaatkan

3. Merubah limbah sampah menjadi barang bernilai ekonomi

4. Menciptakan lingkungan bersih dan asri

\section{Teknik Pengolahan Sampah Menjadi Barang Bernilai Ekonomis}

1. Melakukan pemisahan sampah kering dan sampah basah, sampah basah bisa di olah menjadi kompos. Kompos adalah hasil penguraian parsial/tidak lengkap dari campuran bahan-bahan organik yang dapat dipercepat secara artifisial oleh populasi berbagai macam mikroba dalam kondisi lingkungan yang hangat, lembap, dan aerobik atau anaerobik (Modifikasi dari J.H. Crawford, 2003).

Sampah kering atau limbah padat diantaranya adalah benda-benda yang berbentuk plastik, aluminium, besi, kaleng, botol/beling/kaca, dan lain sebagainya dapat di gunakan sebagai hasil karya kreatif yang mempunyai nilai ekonomis 


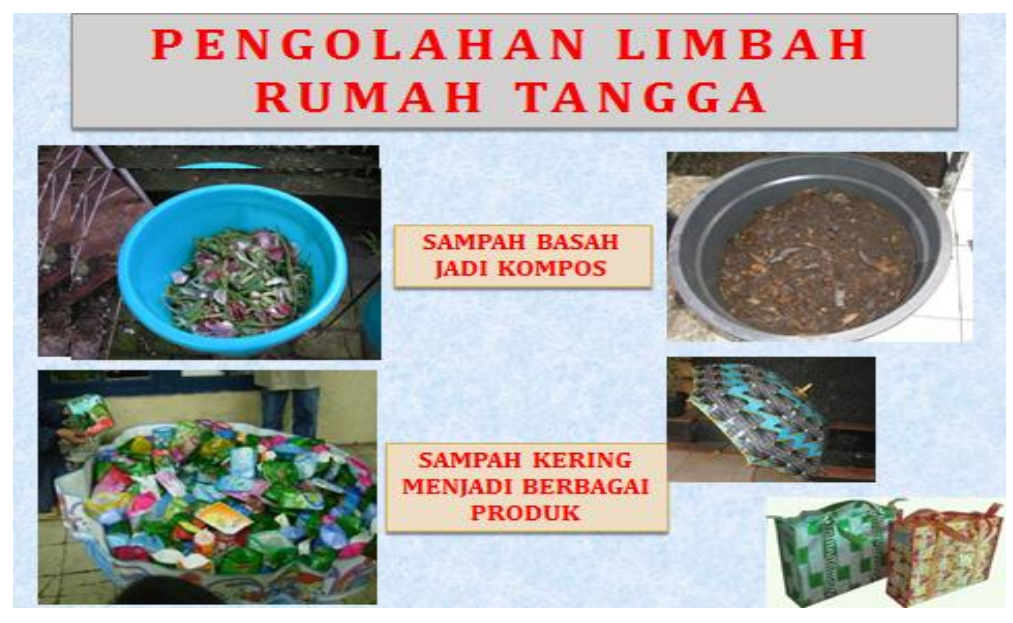

Gambar 3. Pemilahan sampah

2. Jenis- jenis sampah kering yang bisa di olah menjadi barang bernilai ekonomis

Tabel 2. Jenis- Jenis Sampah Kering

\begin{tabular}{lcc}
\hline Sampah Kertas & Sampah Plastik & Logam Kaca \\
\hline 1. Surat Kabar & 1. Tas Plastik & 1. Kaleng \\
2. Kardus & 2. Kantong & 2. Seng \\
3. Kotak & Plastik & 3. Paku \\
Makanan & 3. Botol & 4. Besi Beton \\
4. Buram & 4inuman & 5. Kran Air \\
5. Karton & 4. Gelas & 6. Botol Kaca \\
6. HVS & 5inuman & 7. Gelas Kaca \\
7. Bungkus & 5. Ember & 8. Piring Kaca \\
Rokok & 6. Botol Sampo & 9. Barang/ alat \\
8. Buku & 7. Mainan Anak & berbahan \\
9. Kalender & 8. Pipa Paralon & logam/ kaca \\
& 9. Karpet & \\
& 10. Barang/ & \\
& Peralatan & \\
& berbahan & \\
& plastic yang & \\
& tidak berlapis & aluminium \\
\end{tabular}

3. Sistem pengolahan limbah plastic dapat dikerjakan dengan beberapa cara yaitu

a. Sistem jahit.Menjahit adalah pekerjaan menyambung kain, bulu, kulit binatang,atau bahan-bahan lain yang bisa dilewati jarum jahit dan benang. Menjahitdapat dilakukan dengan tangan memakai jarum tangan atau dengan mesin jahit. 
b. Sistem Anyam. Anyaman merupakan proses menyilangkan, melipat, melilit bahanbahan dari tumbuh-tumbuhan, dan bahan bekas sampah plastikuntuk dijadikan satu kumpulan yang kuat dan boleh digunakan. Bahan-bahan yang bolehdigunakan antara lainbungkus permen, bungkus sabun kemasan, Koran, lidi,buluh,pandan, akar, mengkuang dan sebagainya, bahan ini biasanyamudah dikeringkan dan lembut.

Sistem anyam ini terbagi 3 yaitu :
a. Anyam Lipat
b. Anyam Rotan
c. Anyam Tikar
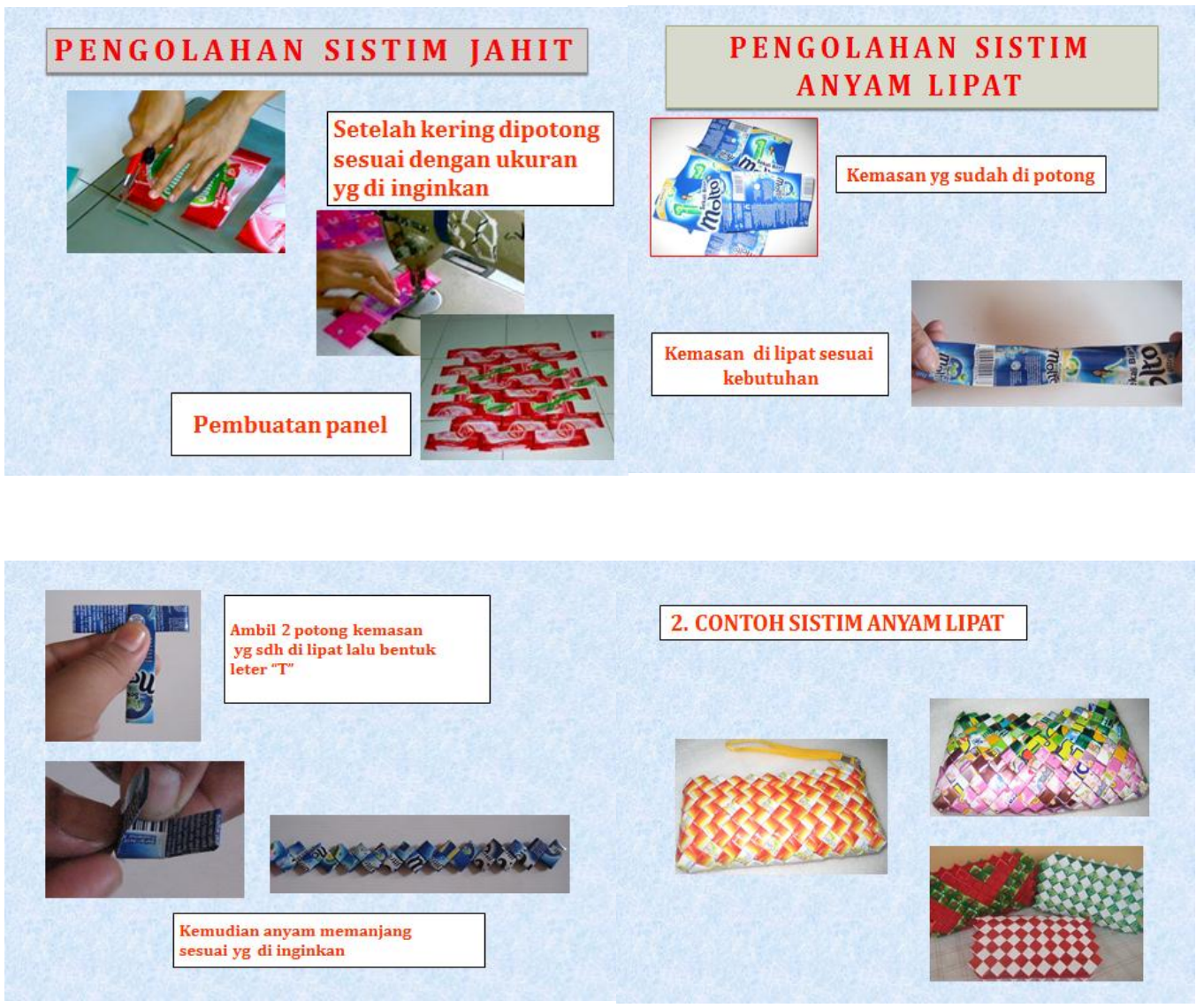

Gambar 4. Sistem Anyaman

\section{Pemasaran Produk}

Menurut William J. Stanton, produk secara sempit dapat diartikan sebagai sekumpulan atribut fisik yang secara nyata terkait dalam sebuah bentuk dapat diidentifikasikan. Sedangkan secara luas, produk merupakan sekumpulan atribut yang nyata dan tidak nyata 
yang didalamnya mencakup warna, kemasan, harga, presise pengecer, dan pelayanan dari pabrik dan pengecer yang mungkin diterima oleh pembeli sebagai sebuah hal yang dapat memberikan kepuasan atas keinginannya.

Secara umum pemasaran dapat memiliki arti sebagai salah satu upaya untuk mengenalkan barang ataupun jasa melalui promosi agar para konsumen tertarik dan melakukan aksi (membeli/menggunakan) demi tercipta penawaran yang kemudian dapat memenuhi kebutuhan masing-masing.

Mengawali pengertian pemasaran menurut Kotler merupakan salah satu bentuk dari proses social dan bagian dari memanagemen diri ataupun kelompok untuk mendapatkan kebutuhannya dengan menciptakan sebuah peluang, pertukaran, maupun penawaran terhadap sekelompok orang yang juga turut memiliki

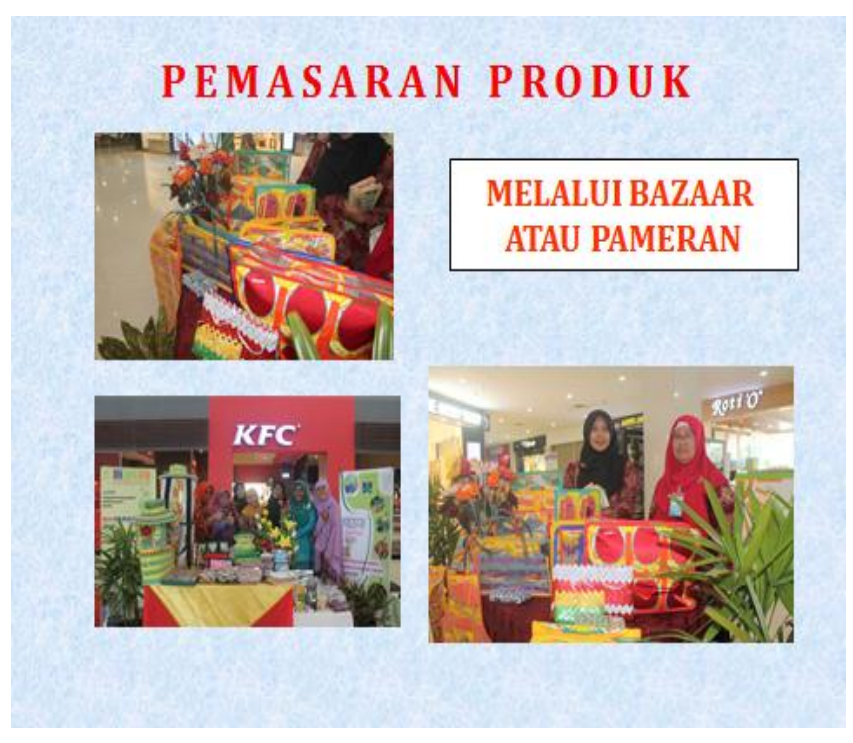

Gambar 5. Pemasaran Produk

Ada 9 (Sembilan) strategi yang dapat dilakukan menurut Ryan Gondo Kusumo (2016). Starategi ini bertujuan meningkatkan income atau pendapatan Masyarakat Sungai Pelunggut, adapun ke Sembilan Strategi itu sebagai berikut:

1. Menggunakan media social

2. Menjadi sponsor sebuah acara atau lomba

3. Bagi- bagi produk

4. Mendata pelanggan/ target market

5. Berikan insentif untuk setiap rekomendasi 
6. Tempatkan produk di tempat yang tepat

7. Lakukan kegiatan amal/ CSR

8. Gunakan Barang Promosi

9. Susun acara untuk mengapresiasi pelanggan

\section{KESIMPULAN}

1. Kelurahan Sungai Pelunggut adalah salah satu wilayah yang menghasilkan sampah yang tingkat kewaspadaannya adalah merah serta kurangnya kesadaran masyarakat akan kebersihan sehingga menimbulkan berbagaimacam pencemaran

2. Mengolah limbah sampah menjadi barang bernilai ekonomi s dapat merubah pola pikir masyarakat setempat untuk peduli hidup sehat dan membatu perekonomian keluarga

3. Strategi pemasaran produk dapat menambah pendapatan keluarga

\section{REFERENSI}

BPSKotaBatam.(2015).StatistikDaerahKecamatanSagulungKotaBatam2015.Batam: Badan PusatStatistikKotaBatam.

Dinas Lingkungan Hidup Kota Batam (2017) Naikkan target pendapatan dari retribusi sampahdiaksesdari:http://www.tribunnews.com.

Philip Kotler (2000:4) Pengertian Pemasaranproses social dan bagian dari memanagemen diri ataupun kelompok untuk mendapatkan kebutuhan

Ryan Godoku Sumo, 2016. 9 Tips strategi pemasaran yang dapat meningkatkan income masyarakat

Antun Atika Sari, 2009, Modul Busana, Pemalang Cipta Gading. Teknik menjahit yang benar

Kementrian Negara Lingkungan Hidup, KNLH 2008, Indonesia setiap tahunnya menghasilkan sampah sebanyak 38,5

Gunawan G, 2007, Mengelola sampah menjadi uang, Transmedia Pustaka, Jakarta

Pratama Al, 2008, Kajian hubungan antara timbunan sampah domestic dengan factor factor yang mempengaruhinya 
Willian J. Stanton, (2000:4) Pengertian pemasaran memankloter

Chandra, (2006).World Health Organization (WHO) sampah adalah sesuatu yang tidak digunakan, tidak dipakai, tidak disenangi atau sesuatu yang dibuang yang berasal dari kegiatan manusia dan tidak terjadi dengan sendirinya

Gelbert dkk (1996;46-48) Potensi bahaya kesehatan yang dapat ditimbulkan oleh sampah. 